\title{
WKŁADKA PIECTRZĄCA ZWIĘKSZAJĄCA EFEKTYWNOŚĆ HYDRAULICZNĄ PRZELEWÓW KONWENCJONALNYCH
}

\begin{abstract}
W artykule przedstawiono rozwiązanie wkładki piętrzącej, wykonywanej na końcu kanału dopływowego do konwencjonalnego przelewu burzowego. Wykonanie wkładki piętrzącej pozwala na poprawę efektywności działania przelewu burzowego, poprzez zwiększenie różnicy pomiędzy zwierciadłami ścieków na końcu kanału dopływowego i początku kanału odpływowego z przelewu burzowego w kierunku oczyszczalni ścieków. Przedstawiona wkładka piętrząca stanowi efektywną alternatywę w odniesieniu do obecnie stosowanych sposobów poprawy efektywności działania tego typu przelewów burzowych. W artykule, wraz z metodyką wymiarowania, przedstawiono również tok obliczeniowy wyznaczania geometrii wkładki piętrzącej, zamieszczając dwa przykłady jej wymiarowania.
\end{abstract}

Słowa kluczowe: kanalizacja ogólnospławna, wymiarowanie, przelewy burzowe, przepływ miarodajny

\section{Wprowadzenie}

Kanalizacja ogólnospławna służy to transportu wszystkich rodzajów ścieków powstałych na terenie zlewni. Duże zróżnicowanie ilościowe transportowanych ścieków deszczowych w porównaniu do ścieków sanitarnych, wymaga rezerwowania dużych powierzchni poprzecznych przekrojów kolektorów, w celu zapewnienia działania kanalizacji w sposób grawitacyjny [7, 8].

Elementem sterującym przepływem ścieków ogólnospławnych w czasie intensywnych opadów deszczu jest przelew burzowy. Jego rola sprowadza się do rozdziału strugi dopływających ścieków na kierowany do oczyszczalni określony ich strumień, a ich nadmiar jest odprowadzany przez przelew burzowy do

\footnotetext{
${ }^{1}$ Autor do korespondencji / corresponding author: Józef Dziopak, Politechnika Rzeszowska, Zakład Infrastruktury i Ekorozwoju, Wydział Budownictwa, Inżynierii Środowiska i Architektury, 35-959 Rzeszów, al. Powstańców Warszawy 6, tel. +48 (017) 865 1817, jdziopak@ @rz.edu.pl 2 Mariusz Starzec, Politechnika Rzeszowska, Zakład Infrastruktury i Ekorozwoju, Wydział Budownictwa, Inżynierii Środowiska i Architektury, 35-959 Rzeszów, al. Powstańców Warszawy 6, tel. +48 (017) 743 2409, mstarzec1990@ prz.edu.pl
} 
odbiornika [10]. Ścisła zależność wielkości strumienia ścieków deszczowych kierowanych do oczyszczalni ścieków od wielkości spływu ścieków bytowo-gospodarczych w okresie pogody bezdeszczowej wymusza na eksploatatorze sieci okresowe sporządzanie bilansu ścieków na przelewie burzowym [9].

Przelewy burzowe stosuje się do hydraulicznego odciążenia oczyszczalni ścieków, jak i zmniejszenia średnic przewodów kanalizacji ogólnospławnej, które łączą te obiekty na trasie spływu ścieków do miejsca ich oczyszczania [3]. Racjonalna lokalizacja przelewów burzowych przekłada się też na znaczne obniżenie kosztów inwestycyjnych $[1,2]$.

\section{Bilans ścieków na przelewie burzowym}

Biorąc pod uwagę usytuowanie w planie oraz położenie krawędzi przelewowej w stosunku do osi kanału dopływowego przelewy burzowe dzieli na czołowe, ukośne i boczne. We wszystkich rodzajach przelewów burzowych bez dławienia odpływu, efektywność ich działania zależy głównie od długości krawędzi przelewowej $L_{p}$ i różnicy położenia zwierciadeł ścieków pomiędzy kanałami dopływowym $h_{g}$ i odpływowym $h_{d}$.

W zależności od przyjętego materiału, z którego wykonane są przewody sieci kanalizacyjnej, okres eksploatacji systemu może wynosić nawet sto lat i więcej. W tak długim okresie eksploatacji kanalizacji ogólnospławnej bilans ścieków, jak i normy prawne (regulujące ilościowy podział strugi dopływających ścieków) ulegną kilkukrotnej zmianie, co będzie wymuszać modernizację lub przebudowę urządzeń z nią współpracujących $[4,5]$.

Zwiększenie ilości ścieków bytowo-gospodarczych dopływających do przelewu burzowego podczas eksploatacji systemu spowoduje zwiększenie ilości ścieków ogólnospławnych, które wymagają skierowania w stronę oczyszczalni ścieków. Najczęściej jest on spowodowany wzrostem wartości wskaźnika jednostkowego odpływu ścieków sanitarnych ze zlewni lub wprowadzeniem ścieków sanitarnych z nowej zlewni kanalizacji sanitarnej dołączonej do istniejącego systemu. Ścieki bytowo-gospodarcze stanowią na ogół niewielką część ścieków, które dopływają do przelewu burzowego w czasie intensywnych opadów atmosferycznych. Tak więc, nawet znaczne procentowe zwiększenie ilości ścieków bytowo-gospodarczych praktycznie nie wpływa negatywnie na hydrauliczne działanie kanalizacji ogólnospławnej przed przelewem burzowym.

Inaczej sprawa wygląda w kolektorze odpływowym z przelewu burzowego. Jeżeli bilans ścieków na przelewie burzowym był wykonany metodą rozcieńczeń, to ilość ścieków ogólnospławnych kierowanych tym kanałem w stronę oczyszczalni jest sumą ilości ścieków bytowo-gospodarczych dopływających do przelewu burzowego oraz tej ilości ścieków pomnożonej przez przyjętą wartość współczynnika rozcieńczenia początkowego ścieków $n_{r p}$. Bilans ścieków wyznaczony metodą rozcieńczeń na przelewie przedstawiono na rysunku 1. 
Wzrost ilość ścieków bytowo-gospodarczych dopływających do przelewu burzowego, przy stałej wartości współczynnika rozcieńczenia początkowego ścieków, spowoduje taki sam wzrost procentowy ilości ścieków ogólnospławnych odpływających z przelewu burzowego w stronę oczyszczalni. Zwiększenie ilości ścieków ogólnospławnych kierowanych w stronę oczyszczalni spowoduje odpowiednie zwiększenie napełnienia w kolektorze odpływowym.

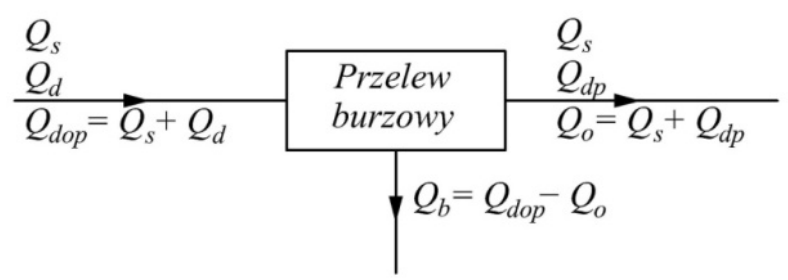

Rys. 1. Schemat bilansu ścieków na przelewie burzowym: $Q_{s}$ - ilość ścieków bytowo-gospodarczych dopływających do przelewu burzowego, $Q_{d}$ - całkowita ilość ścieków deszczowych dopływających do przelewu burzowego, $Q_{d o p}$ ilość ścieków dopływających do przelewu burzowego, $Q_{d p}$ - ilość ścieków deszczowych odpływających z przelewu burzowego w kierunku oczyszczalni, $Q_{o}$ - ilość ścieków za przelewem burzowym płynących w kierunku oczyszczalni, $Q_{b}$ - ilość ścieków ogólnospławnych odprowadzanych kanałem burzowym do odbiornika

Fig. 1.The balance of waste water in storm overflow: $Q_{s}$ - the amount of municipal wastewater inflow into storm overflow, $Q_{d}$ - the amount of storm wastewater inflow into storm overflow, $Q_{d o p}$-the amount of wastewater inflow into storm overflow, $Q_{d p}$ - the amount of storm waste- water outflowing from storm overflow, $Q_{o}$ - the amount of wastewater outflowing from storm overflow to sewage treatment plant, $Q_{b}$ - the amount of combined wastewater outflowing to receiver

Krawędź przelewowa jest umieszczana w konwencjonalnych przelewach burzowych na wysokości zwierciadła ścieków w kanale odpływowym, przy przepływie granicznym obliczonym z zależności (1):

$$
Q_{o}=Q_{s}+Q_{d p}
$$

gdzie: $Q_{o}$ - ilość ścieków ogólnospławnych odpływających z przelewu burzowego w kierunku oczyszczalni, $\mathrm{dm}^{3} / \mathrm{s}$;

$Q_{s}$ - ilość ścieków bytowo-gospodarczych dopływających do przelewu burzowego, $\mathrm{dm}^{3} / \mathrm{s}$;

$Q_{d p}$ - ilość ścieków deszczowych odpływających z przelewu burzowego w kierunku oczyszczalni, $\mathrm{dm}^{3} / \mathrm{s}$.

Niezależnie od aktualnego bilansu ścieków deszczowych przed przelewem burzowym, wzrost ilości ścieków bytowo-gospodarczych dopływających do przelewu burzowego zawsze spowoduje potrzebę podniesienia krawędzi przelewowej, jeżeli długość przelewu nie ulegnie wydłużeniu.

Prawidłowe funkcjonowanie przelewu burzowego po zwiększeniu odpływu strumienia ścieków w kierunku oczyszczalni jest możliwe w czterech przypadkach, z których trzy są trudne do spełnienia w praktyce, chociaż możliwe. Pierwszy, przez wydłużenie długości krawędzi przelewowej w wyniku rozbudowy przelewu burzowego. 
Drugi, przez odpowiednie zwiększenie przekroju kolektora odpływowego z przelewu burzowego, w przypadku jednocześnie uzasadnionej rekonstrukcji polegającej na jego wymianie, przykładowo metodą bezodkrywkową.

Trzecim sposobem jest obniżenie dna kanału odpływowego, możliwe tylko przy wymianie istniejącego kanału na nowy, jednak uzależnione jest to od wysokościowego położenia kolektora na trasie $\mathrm{z}$ analizowanego przelewu w kierunku kolejnego, i tak aż do oczyszczalni ścieków. Porównując te trzy opisane warianty, za najbardziej korzystne rozwiązanie należy uznać wydłużenie krawędzi przelewowej.

Jednak każdy z nich jest kosztowny i zarazem trudny do realizacji podczas eksploatacji sieci. Biorąc powyższe pod uwagę opracowano oryginalne rozwiązanie polegające na zamontowaniu specjalnej wkładki na wylocie kolektora dopływowego do przelewu burzowego, której zadaniem jest podniesienie zwierciadła ścieków do poziomu zapewniającego wydajność przelewu przy istniejącej długości jego krawędzi. Stosowanie takiej wkładki o określonym profilu ma uzasadnienie i jest zalecane, gdy jej montaż nie spowoduje spiętrzenia ścieków w kolektorze dopływowym, wymuszającym jego działanie pod ciśnieniem.

Ze względu na większy procentowy udział ścieków bytowo-gospodarczych w ilości ścieków odpływających z przelewu, wpłynie on na zmniejszenie się różnicy wysokości pomiędzy zwierciadłami w kanale dopływowym i odpływowym z przelewu burzowego. Wówczas istniejąca długość krawędzi przelewowej okazuje się za krótka, co przedstawiono na rysunku 2.

Modernizacja konwencjonalnego przelewu burzowego jest również wymagana, gdy zwiększeniu ulegnie ilość ścieków deszczowych, które wymagają odprowadzenia w stronę oczyszczalni ścieków. W tym przypadku ilość ścieków dopływających do przelewu burzowego oraz poziom zwierciadła ścieków na końcu kanału dopływowego nie ulegają zmianie. Przeciwnie sytuacja wygląda w kanale odpływowym, gdzie po modernizacji napełnienie ścieków osiąga większą wartość, co wymusza konieczność podniesienia poziomu krawędzi przelewowej. Podniesienie wysokości krawędzi przelewowej bez uwzględnienia zmiany bilansu ścieków dopływających do przelewu burzowego obniża efektywność hydrauliczną przelewu burzowego. W praktyce oznacza to, że już niewielkie podniesienie krawędzi przelewowej spowoduje nieprawidłowy rozdział strugi ścieków dopływających do przelewu burzowego.

W sytuacji, gdy długość krawędzi przelewowej okaże się zbyt krótka, napełnienie ścieków w kanale odpływowym z przelewu burzowego będzie znajdować się powyżej poziomu krawędzi przelewowej. $\mathrm{Z}$ tego względu w stronę oczyszczalni ścieków odpływać będzie większa ilość ścieków ogólnospławnych, czego częstym skutkiem będzie ciśnieniowe działanie kolektorów znajdujących się poniżej przelewu burzowego na trasie spływu ścieków w kierunku oczyszczalni. 


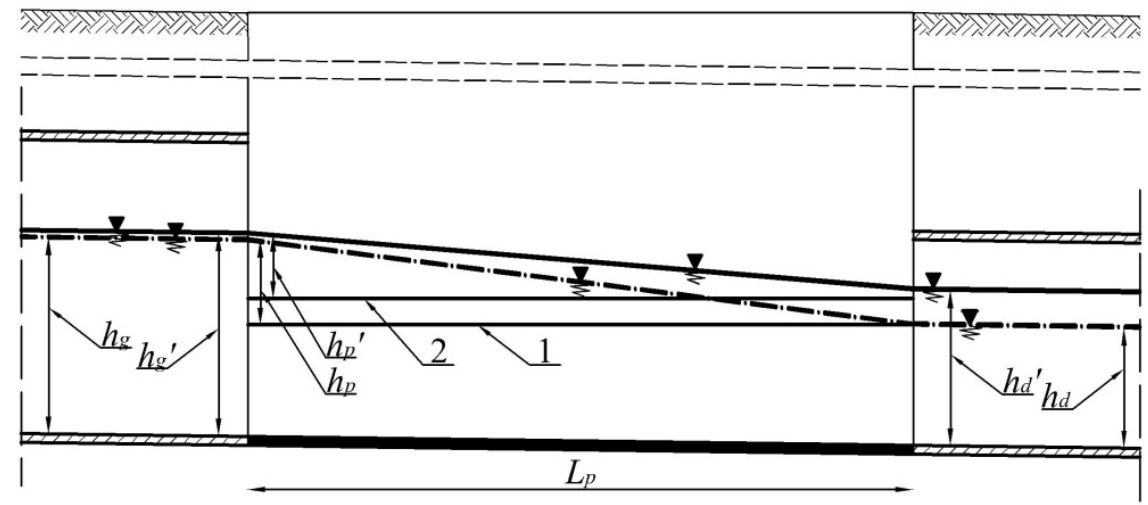

Rys. 2. Wysokość zwierciadeł ścieków i położenie krawędzi przelewowej w przelewie burzowym: 1 - położenie krawędzi przelewowej przed zmianą bilansu ścieków, 2 - położenie krawędzi przelewowej odpowiadające wymaganej wysokości zwierciadła ścieków na wlocie do kanału odpływowego, wyznaczonej w oparciu o nowy bilans ścieków, $L_{p}$ - długość krawędzi przelewowej, $h_{g}$ - wysokość zwierciadła ścieków w kanale dopływowym przed zmianą bilansu ścieków, $h_{g}$ ' - wysokość zwierciadła ścieków w kanale dopływowym po zmianie bilansu ścieków, $h_{p}$ - różnica położenia zwierciadła ścieków w kanałach dopływowym i odpływowym przed zmianą bilansu ścieków, $h_{p}$ ' - różnica położenia zwierciadła ścieków w kanałach dopływowym i odpływowym po zmianie bilansu ścieków, $h_{d}$ - wysokość zwierciadła ścieków w kanale odpływowym przed zmianą bilansu ścieków, $h_{d}$ ' - wysokość zwierciadła ścieków w kanale odpływowym po zmianie bilansu ścieków i podniesieniu krawędzi przelewowej z poziomu 1 do 2

Fig. 2. The height of wastewater table and position overflow edge in storm overflow: 1 - position overflow edge before the change in the balance of sewage, 2 - position overflow edge equal to the required height of wastewater table at the inlet of outflow canal, determined from the new balance of sewage, $L_{p}$ - the length of the overflow edge, $h_{g}$ - the height of wastewater table at the inflow canal before the change in the balance of sewage, $h_{g}$ ' - the height of wastewater table at the inflow canal after the change in the balance of sewage, $h_{p}$ - the difference in the position of the sewage table in inlet and outlet canals before the change in the balance of sewage, $h_{p}{ }^{\prime}$ - the difference in the position of the sewage table in inlet and outlet canals after the change in the balance of sewage, $h_{d}$ - the height of wastewater table at the outflow canal before the change in the balance of sewage, $h_{d}{ }^{\prime}$ - the height of wastewater table at the outflow canal after the change in the balance of sewage

Przedłużenie krawędzi przelewowej, przez którą przelewają się ścieki burzowe wiążę się w większości przypadków z kosztowną modernizacją przelewu burzowego. Na efektywność działania konwencjonalnego przelewu burzowego oprócz długości krawędzi przelewnej ma wpływ różnica wysokości pomiędzy zwierciadłami ścieków w kanałach dopływowym i odpływowym. Wysokość napełnienia w kanale odpływowym, odprowadzającym ścieki ogólnospławne z przelewu burzowego w stronę oczyszczalni, jest uzależniona od kilku czynników. Głownie zależy ona od średnicy kanału odpływowego, spadku tego kanału i natężenia przepływu ścieków w tym kolektorze. Taka sama sytuacja odnosi się do kanału dopływowego do przelewu. Obniżenie zwierciadła ścieków w kanale odpływowym bez zmiany jego geometrii lub obniżenia dna jest raczej możliwe, ale praktycznie bardzo drogie i mało realne do przyjęcia.

Biorac pod uwage te uwarunkowania za najkorzystniejsze przyjęto zwiększenia różnicy pomiędzy zwierciadłami, które można uzyskać przez spiętrzenie ścieków na wlocie kanału dopływowego do przelewu burzowego. Zainstalowanie wkładki piętrzącej o odpowiednich kształtach i wymiarach na końcu kanału dopływowego do przelewu burzowego zapewni podniesienie się zwierciadła 
ścieków w tym kanale (rys. 3). Efektem tego jest zwężenie kanału, co skutkuje wypiętrzeniem ścieków do wymaganej wysokości $h_{p}$ ", którą można wyznaczyć stosując sformułowaną metodykę obliczeń. Jest to rozwiązanie skuteczne, a zarazem proste, i które nie generuje znacznych kosztów inwestycyjnych [6].

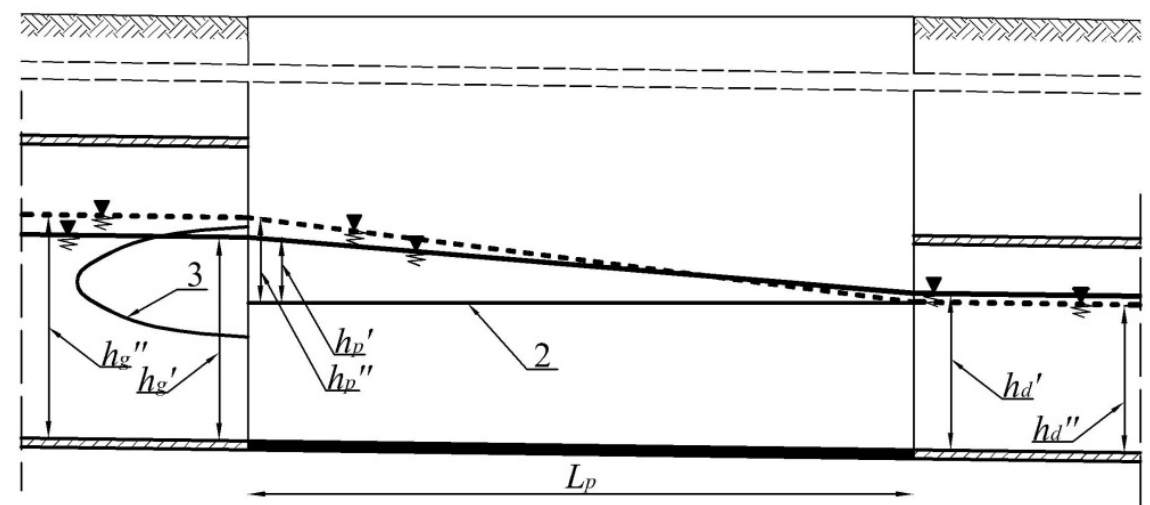

Rys. 3. Wysokości zwierciadeł ścieków w przelewie burzowym po zmianie bilansu ścieków: 3 - wkładka piętrząca, $h_{g}$ " - wysokość zwierciadła ścieków w kanale dopływowym po wykonaniu wkładki piętrzącej, $h_{p}$ " - różnica położenia zwierciadeł ścieków w kanałach dopływowym i odpływowym po wykonaniu wkładki piętrzącej, $h_{d}$ " - wysokość zwierciadła ścieków w kanale odpływowym po wykonaniu wkładki piętrzącej

Fig. 3.The height of wastewater table in storm overflow after the change in the balance of sewage: 3 - uplifting insert, $h_{g}$ " - the height of wastewater table at the inflow canal after performing uplifting insert, $h_{p}$ " - the difference in the position of the sewage table in inlet and outlet canals after performing uplifting insert, $h_{d}$ " - the height of wastewater table at the outflow canal after performing uplifting insert

\section{Metodyka wymiarowania wkładki piętrzącej}

Wykonanie wkładki piętrzącej ma na celu wywołanie określonego spiętrzenia ścieków na końcu kolektora dopływowego do przelewu burzowego. Wkładka jest wykonywana głównie przy modernizacji istniejącego przelewu burzowego, gdy okazuje się, że istniejąca długość krawędzi przelewu burzowego konwencjonalnego jest za krótka, aby zapewnić odprowadzenie wyznaczonego z nowego bilansu nadmiaru ścieków ogólnospławnych. W wyniku spiętrzenia ścieków uzyskuje się ustaloną średnią wysokość strugi nad krawędzią przelewową przelewu burzowego.

Geometrię wkładki piętrzącej dobiera się indywidualnie, tak aby zapewnić wymaganą różnicę pomiędzy zwierciadłami w kanałach dopływowym i odpływowym $h_{p}$ "', która umożliwia poprawne działanie już eksploatowanego przelewu burzowego.

Dużą zaletą wkładki piętrzącej jest przede wszystkim jej prosta budowa. Można ją wykonać jako prefabrykowany element $\mathrm{z}$ dowolnego materiału stosowanego w sieciach kanalizacyjnych. Wkładka piętrząca może stanowić pojedyn- 
czy element (rys. 4a) lub składać się z kilku członów odpowiednio połączonych ze sobą za pomocą odpowiednich łączników (rys. 4b).

Zastosowanie modułowej konstrukcji wkładki pozwala na szybką i prostą zmianę parametrów funkcjonowania przelewu, które można dostosować do zaistniałej sytuacji sporządzając aktualny bilans ścieków. Zmianę geometrii wkładki uzyskuje się poprzez dodanie lub zmniejszenie liczby zainstalowanych modułów. Dodawanie modułów wpływa na podnoszenie się zwierciadła ścieków na wylocie kanału dopływowego, co przekłada się na wzrost efektywności działania przelewu burzowego. Analogicznie, zmniejszenie liczby modułów wkładki piętrzącej spowoduje obniżenie się zwierciadła ścieków na końcu kanału dopływowego. Zatem w wyniku zastosowania wkładki piętrzącej można w łatwy sposób zmieniać parametry hydrauliczne konwencjonalnego przelewu burzowego, $\mathrm{i}$ to bez ingerencji w jego konstrukcję.

a)

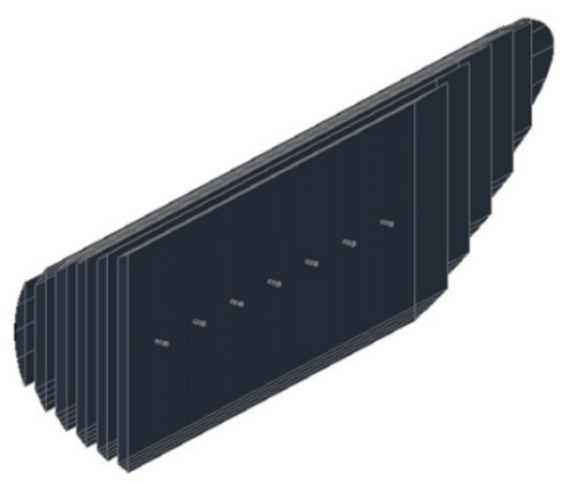

b)

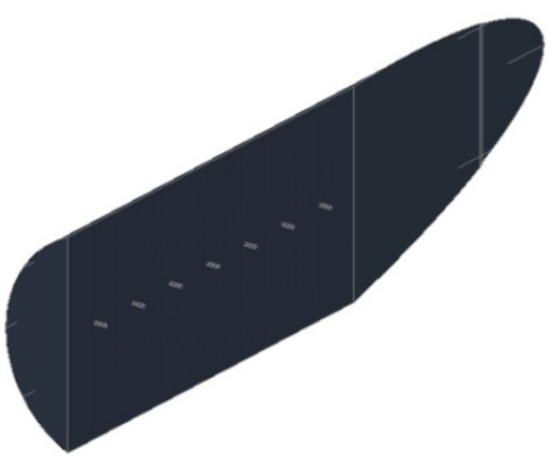

Rys. 4. Konstrukcja wkładki piętrzącej: a) modułowa, b) monolityczna

Fig. 4. The construction of uplifting insert: a) modular, b) monolithic

Zainstalowanie wkładki piętrzącej na wewnętrznej ścianie przewodu dopływowego przed wlotem do przelewu burzowego może być rozwiązane przez jej przyklejenie za pomocą odpowiedniego kleju lub wykorzystując śruby rozpo- 
rowe. Mocowanie wkładki piętrzącej za pomocą śrub rozporowych jest wskazane przede wszystkim przy jej użyciu jako konstrukcji modułowej. Pozwala to w bardzo prosty i szybki sposób demontować lub dodawać poszczególne moduły wkładki.

Geometrię wkładki piętrzącej dostosowuje się do wymaganej efektywności działania przelewu burzowego lub innego obiektu rozdzielającego przepływ na dwa strumienie.

W pracy przedstawiono tok obliczeniowy wymiarowania klasycznego rozwiązania wkładki piętrzącej, zamontowanej w kanale dopływowym do przelewu burzowego o przekroju kołowym. Podany tok obliczeniowy dotyczy wkładki piętrzącej składającej się z dwóch bliźniaczych elementów o schemacie ich umiejscowienia na końcu kanału dopływowego do przelewu burzowego, który przedstawiono na rysunku 5. Ściany wkładki piętrzącej mają bezpośredni kontakt z przepływającymi ściekami i są usytuowane prostopadłe do osi kanału.

W pierwszym etapie należy wyznaczyć pole powierzchni przekroju poprzecznego zajmowane przez przepływ obliczeniowy na końcu kanału dopływowego do przelewu burzowego przed wykonaniem wkładki piętrzącej ze wzoru (2):

$$
f_{k c z}=\frac{\Pi \cdot d^{2}}{4} \cdot \frac{\gamma}{360^{o}}-\frac{d^{2}}{8} \cdot \sin \gamma
$$

Kąt środkowy $\gamma$ wyznaczony przez zwierciadło ścieków na końcu kanału dopływowego do przelewu burzowego ustala się w zależności od wysokości zwierciadła ścieków w tym kanale, i tak:

- przy $h_{g}{ }^{\prime} \leq d / 2$ należy zastosować wzór (3)

$$
\gamma=2 \arccos \frac{\frac{d}{2}-h_{g}^{\prime}}{\frac{d}{2}}
$$

- zaś przy $h_{g}{ }^{\prime}>d / 2$ zależność opisaną relacją (4)

$$
\gamma=360^{\circ}-2 \arccos \frac{h_{g}^{\prime}-\frac{d}{2}}{\frac{d}{2}}
$$

Drugim krokiem jest wyznaczenie wysokości spiętrzenia ścieków na końcu kanału dopływowego $h_{g}$ " po zmianie bilansu ścieków, która zapewni wymaganą efektywność hydrauliczną eksploatowanego przelewu burzowego bez konieczności modernizacji jego konstrukcji. 
a)

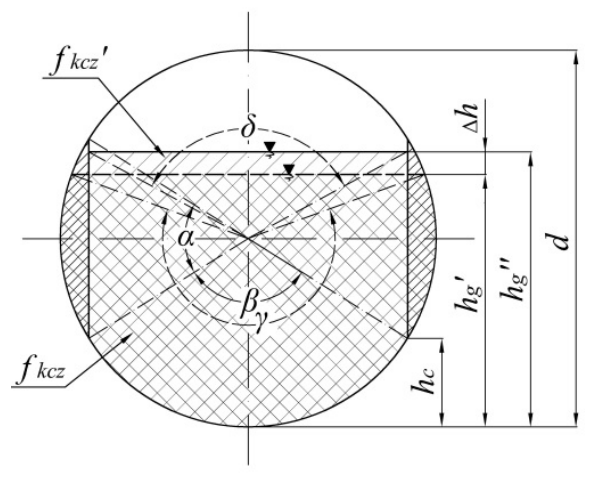

b)

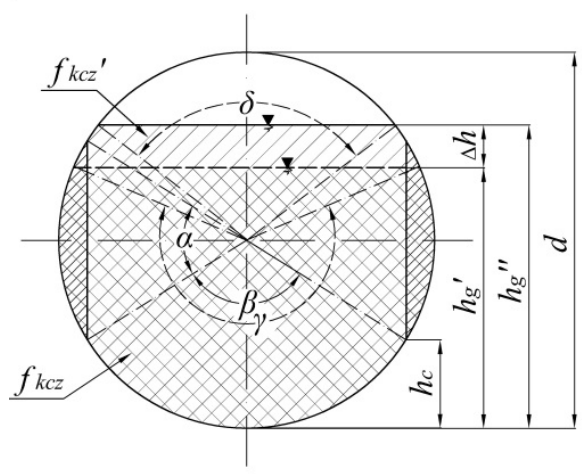

Rys. 5. Schemat umieszczonej wkładki piętrzącej na końcu kanały dopływowego do konwencjonalnego przelewu burzowego: a) zwierciadło ścieków znajduje się poniżej górnej krawędzi wkładki piętrzącej, b) zwierciadło ścieków znajduje się powyżej górnej krawędzi wkładki piętrzącej: $d$ - średnica kanału dopływowego do przelewu burzowego, $\beta$ - kąt środkowy wyznaczony przez dolną krawędź wkładki piętrzącej, $\gamma$ - kąt środkowy wyznaczony przez zwierciadło ścieków, $\alpha$ - kąt środkowy wyznaczony przez dolną i górną krawędź wkładki piętrzacej, $\delta$ - kạt środkowy wyznaczony przez zwierciadło ścieków po wykonaniu wkładki piętrzącej, $\Delta h$ - różnica w poziomie napełnienia ścieków na końcu kanału dopływowego wywołana zainstalowaniem wkładki piętrzącej, $f_{k c z^{-}}$powierzchnia czynna kanału zajmowana przez przepływ obliczeniowy przed wykonaniem wkładki piętrzącej, $f_{k c z}$ - powierzchnia czynna kanału zajmowana przez przepływ obliczeniowy po wykonaniu wkładki piętrzącej, $h_{c}$ - wysokość od dna kanału dopływowego do dolnej krawędzi wkładki piętrzącej)

Fig. 5. Location uplifting insert at the end of the inlet canal to the conventional storm overflow: a) wastewater table below the top edge of uplifting insert, b) wastewater table above the top edge of uplifting insert: $d$ - the diameter of the inlet canal to storm overflow, $\beta$ - the central angle defined by the lower edge of uplifting insert, $\gamma$ - the central angle defined by wastewater table, $\alpha$ - the central angle defined by the lower and upper edge of uplifting insert, $\delta$ - the central angle defined by wastewater table after performing uplifting insert, $\Delta h$ - the difference between wastewater levels at the end of the inlet canal caused by uplifting insert, $f_{k c z^{-}}$active cross section area occupied by flowing wastewater before performing uplifting insert, $f_{k c z}$ '- active cross section area occupied by flowing wastewater after performing uplifting insert, $h_{c}$ - the height from the bottom of the inlet canal to lower edge of uplifting insert

Kolejnym etapem jest wyznaczenie pola powierzchni przekroju czynnego, zajmowanego przez przepływ obliczeniowy po zainstalowaniu wkładki piętrzącej. Przyjmując, że średnia prędkość przepływu ścieków na końcu kanału dopływowego po wykonaniu wkładki piętrzącej nie ulegnie znaczącej zmianie, to wartość pola powierzchni przekroju poprzecznego zajmowanego przez przepływ obliczeniowy na końcu tego kanału również pozostanie niezmienna i spełni wa- 
runek, że $f_{k c z}=f_{k c z}$ '. W innym przypadku, należy wyznaczyć na nowo powierzchnię czynną przekroju $f_{k c z}$ 'zajmowaną przez przepływ obliczeniowy.

Geometrię i wymiary wkładki piętrzącej ustala się wg metody kolejnych przybliżeń. Należy tak dobrać wymiary i geometrię wkładki piętrzącej (kąt środkowy $\beta$ ), aby przy wartości natężenia dopływu ścieków ogólnospławnych $Q_{d o p}$ do przelewu burzowego wyznaczonego na podstawie nowego bilansu ścieków, uzyskać na końcu kanału dopływowego do przelewu wymaganą wysokość spiętrzenia ścieków $h_{g}$ ", która zapewni niezbędną efektywność hydrauliczną przelewu burzowego.

W celu sprawdzenia, czy na końcu kanału dopływowego do przelewu burzowego, przy założonej geometrii wkładki piętrzącej występuje wymagana wysokość spiętrzenia ścieków $h_{g}$ ", należy skorzystać ze wzoru (5):

$$
h_{g}^{\prime \prime}=\frac{f_{k c z}-\frac{\Pi \cdot d^{2}}{4} \cdot \frac{\beta}{360^{\circ}}+\frac{d^{2}}{8} \cdot \sin \beta}{d \cdot \sin \frac{\beta}{2}}+\frac{d}{2} \cdot\left(1-\cos \frac{\beta}{2}\right)
$$

Zależność (5) można stosować wyłącznie wtedy, gdy wysokość zwierciadła ścieków nie przekracza górnej krawędzi wkładki. Z tego względu, dla dobranej geometrii wkładki piętrzącej (dobranego kąta środkowego $\beta$ ) należy w pierwszym etapie sprawdzić, czy zwierciadło ścieków $h_{g}$ " w kanale dopływowym do przelewu burzowego znajduje się poniżej jej górnej krawędzi (stropu). Sprawdzenie tego warunku przedstawia nierówność (6):

$$
h_{g}^{\prime \prime} \leq \frac{d}{2} \cdot\left(1-\cos \frac{\beta}{2}\right)+d \cdot \sin \left(90^{\circ}-\frac{\beta}{2}\right)
$$

Gdy warunek przedstawiony nierównością (6) nie zostanie spełniony należy zastosować odmienny tok obliczeniowy na wyznaczenie geometrii wkładki piętrzącej. W tym celu najpierw wyznacza się pole powierzchni czynnej przekroju poprzecznego $f_{k c z}$ " zajmowane przez przepływ obliczeniowy do poziomu górnej krawędzi wkładki piętrzącej ze wzoru (7):

$$
f_{k c z}{ }^{\prime \prime}=\frac{\Pi \cdot d^{2}}{4} \cdot \frac{\beta}{360^{\circ}}-\frac{d^{2}}{8} \cdot \sin \beta+d \cdot \sin \frac{\beta}{2} \cdot d \cdot \sin \left(90^{\circ}-\frac{\beta}{2}\right)
$$

gdzie $f_{k c z}$ " stanowi pole powierzchni przekroju poprzecznego do poziomu górnej krawędzi wkładki piętrzącej $\mathrm{w} \mathrm{m}^{2}$.

Pozostałe pole powierzchni czynnej przekroju poprzecznego $f_{\text {kczp }}$, zajmowane przez przepływ obliczeniowy ponad krawędziami wkładki, należy obliczyć z zależności (8): 


$$
f_{k c z p}=f_{k c z}-f_{k c z}^{\prime \prime}
$$

gdzie $f_{\text {kczp }}$ jest polem powierzchni czynnej przekroju poprzecznego powyżej poziomu górnej krawędzi wkładki piętrzącej $\mathrm{w} \mathrm{m}^{2}$.

W następnym etapie należy wyznaczyć kąt środkowy $\delta$ ustalony przez zwierciadło ścieków po wykonaniu wkładki piętrzącej ze wzoru (9):

$$
\delta=2 \arccos \left(\frac{h_{g}^{\prime \prime}-\frac{d}{2}}{\frac{d}{2}}\right)
$$

Po wyznaczeniu kąta środowego $\delta$ należy obliczyć pole powierzchni czynnej przekroju poprzecznego $f_{\text {kczp }}$ ' powyżej górnej krawędzi wkładki piętrzącej ze wzoru (10):

$$
f_{k c z p}{ }^{\prime}=\frac{\Pi \cdot d^{2}}{4} \cdot \frac{\beta}{360^{\circ}}-\frac{d^{2}}{8} \cdot \sin \beta-\frac{\Pi \cdot d^{2}}{4} \cdot \frac{\delta}{360^{\circ}}+\frac{d^{2}}{8} \cdot \sin \delta
$$

gdzie $f_{\text {kczp }}$ 'oznacza pole powierzchni przekroju poprzecznego powyżej poziomu górnej krawędzi wkładki piętrzącej $\mathrm{w} \mathrm{m}^{2}$.

Wartości otrzymane z równań (8) i (10) powinny być sobie równe. W innym przypadku należy dobrać inny kąt środkowy $\beta$ i powtórzyć cały tok obliczeniowy.

\section{Przykłady obliczeniowe}

\section{Przykład 1}

Na podstawie sporządzonego bilansu ścieków bytowo-gospodarczych ustalono ich większy dopływ do eksploatowanego przelewu burzowego, co powoduje wzrost napełnienia w kanale odpływowym do oczyszczalni ścieków i wymaga modernizacji. Rozwiązanie zadania polega na zastosowaniu efektywnego rozwiązania w postaci wkładki piętrzącej. Zaproponować geometrię wkładki piętrzącej w kolektorze dopływowym do eksploatowanego przelewu burzowego, ponieważ długość istniejącej krawędzi przelewowej nie zapewnia właściwego rozdziału strugi dopływających ścieków.

Dane wejściowe:

- średnica kanału dopływowego do przelewu burzowego $d=1,2 \mathrm{~m}$,

- napełnienie w kanale dopływowym do przelewu burzowego przed zmianą bilansu ścieków na przelewie $h_{g}=0,68 \mathrm{~m}$, 
- napełnienie w kanale dopływowym do przelewu burzowego przed zastosowaniem wkładki piętrzącej $h_{g}{ }^{\prime}=0,70 \mathrm{~m}$,

- wymagane napełnienie w kanale dopływowym do przelewu burzowego po zainstalowaniu wkładki piętrzącej $h_{g} "=0,77 \mathrm{~m}$,

- napełnienie w kanale odpływowym w kierunku oczyszczalni ścieków $\mathrm{z}$ przelewu burzowego przed zmianą bilansu ścieków na przelewie, $h_{d}=0,45 \mathrm{~m}$,

- napełnienie w kanale odpływowym w kierunku oczyszczalni ścieków $\mathrm{z}$ przelewu burzowego po zmianie bilansu ścieków na przelewie, $h_{d}{ }^{\prime}=0,60 \mathrm{~m}$,

- wymagane napełnienie w kanale odpływowym w kierunku oczyszczalni ścieków z przelewu burzowego po zmianie bilansu ścieków na przelewie, $h_{d}{ }^{\prime}=0,54 \mathrm{~m}$,

- wykonanie wkładki piętrzącej nie zmienia wartości średniej prędkości przepływu ścieków na końcu kanału dopływowego do przelewu.

Kąt środkowy wyznaczony przez zwierciadło ścieków na końcu kanału dopływowego do przelewu burzowego przed wykonaniem wkładki piętrzącej wyznaczono ze wzoru (3):

$$
\gamma=360^{\circ}-2 \arccos \frac{h_{g}^{\prime}-\frac{d}{2}}{\frac{d}{2}}=360^{\circ}-2 \arccos \frac{0,7-0,6}{0,6}=199,19^{\circ}
$$

Pole powierzchni czynnej przekroju poprzecznego, zajmowane przez przepływ obliczeniowy na końcu kanału dopływowego do przelewu burzowego bocznego przed wykonaniem wkładki piętrzącej, ustalono na podstawie równania (1):

$$
\begin{aligned}
& f_{k c z}=\frac{\Pi \cdot d^{2}}{4} \cdot \frac{\gamma}{360^{\circ}}-\frac{d^{2}}{8} \cdot \sin \gamma=\frac{\Pi \cdot 1,2^{2}}{4} \cdot \frac{199,19^{\circ}}{360^{\circ}}-\frac{1,2^{2}}{8} \cdot \sin 199,19^{\circ}= \\
& =0,6849 \mathrm{~m}^{2}
\end{aligned}
$$

Pole powierzchni czynnej zajmowane przez przepływ obliczeniowy po wykonaniu wkładki piętrzącej nie ulega zmianie, a więc powierzchnie $f_{k c z}=f_{k c z}$ '.

Zakładając wartość kąta środkowego równą $\beta=111^{\circ}$, wyznaczono wymaganą wysokość spiętrzenia ścieków na końcu kanału dopływowego korzystając z zależności (4):

$$
h_{g}{ }^{\prime \prime}=\frac{f_{k c z}{ }^{\prime}-\frac{\Pi \cdot d^{2}}{4} \cdot \frac{\beta}{360^{o}}+\frac{d^{2}}{8} \cdot \sin \beta}{d \cdot \sin \frac{\beta}{2}}+\frac{d}{2} \cdot\left(1-\cos \frac{\beta}{2}\right)=
$$




$$
=\frac{0,6849-\frac{\Pi \cdot 1,2^{2}}{4} \cdot \frac{111^{\circ}}{360^{\circ}}+\frac{1,2^{2}}{8} \cdot \sin 111^{\circ}}{1,2 \cdot \sin \frac{111^{\circ}}{2}}+\frac{1,2}{2} \cdot\left(1-\cos \frac{111^{\circ}}{2}\right)=0,77 \mathrm{~m}
$$

Dla dobranej wkładki piętrzącej sprawdzono czy zwierciadło ścieków nie znajduje się powyżej jej górnej krawędzi korzystając ze wzoru (5):

$$
\begin{aligned}
& h_{g}^{\prime} \leq \frac{d}{2} \cdot\left(1-\cos \frac{\beta}{2}\right)+d \cdot \sin \left(90^{\circ}-\frac{\beta}{2}\right) \\
& 0,77 \leq \frac{1,2}{2} \cdot\left(1-\cos \frac{111^{\circ}}{2}\right)+1,2 \cdot \sin \left(90^{\circ}-\frac{111^{\circ}}{2}\right)
\end{aligned}
$$

$0,77 \mathrm{~m} \leq 0,94 \mathrm{~m}$

W celu uzyskania spiętrzenia ścieków do wysokości $h_{g}{ }^{\prime}{ }^{\prime}=0,77 \mathrm{~m}$, na końcu kanału dopływowego do przelewu burzowego należy wykonać wkładkę piętrzącą o wymiarach przedstawionych na rysunku 6 , zgodnie z wykonanymi obliczeniami.

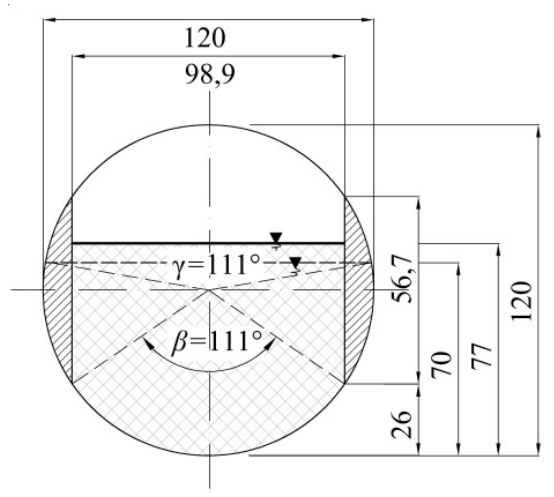

Rys. 6. Schemat usytuowania i geometrii wkładki piętrzącej wykonanej na końcu kanału dopływowego do przelewu burzowego

Fig. 6. Diagram of the location and geometry of uplifting insert performed at the end of the inlet canal to the storm overflow

\section{Przykład 2}

Ze względu na potrzebę odprowadzenia większej ilości ścieków deszczowych w kierunku oczyszczalni ścieków nastąpiła potrzeba podniesienia poziomu 
krawędzi przelewowej. Z tego powodu zmniejszeniu uległa różnica wysokości zwierciadeł ścieków w kanałach dopływowym i odpływowym, co spowodowało obniżenie efektywności hydraulicznej i niepoprawny rozdział strugi dopływających ścieków ogólnospławnych. Rozwiązaniem zadania jest dobranie geometrii wkładki piętrzącej, która pozwoli na podniesienie zwierciadła ścieków w kanale dopływowym o wartość zapewniającą określony rozdział strugi dopływających ścieków.

Dane wejściowe:

- średnica kanału dopływowego do przelewu burzowego $d=0,8 \mathrm{~m}$,

- napełnienie w kanale dopływowym do przelewu burzowego przed zastosowaniem wkładki piętrzącej $h_{g}=h_{g}{ }^{\prime}=0,65 \mathrm{~m}$,

- wymagane napełnienie w kanale dopływowym do przelewu burzowego po zainstalowaniu wkładki piętrzącej $h_{g} "=0,71 \mathrm{~m}$,

- napełnienie w kanale odpływowym w kierunku oczyszczalni ścieków z przelewu burzowego przed zmianą ilości ścieków odpływających w kierunku oczyszczalni ścieków, $h_{d}=0,34 \mathrm{~m}$,

- napełnienie w kanale odpływowym w kierunku oczyszczalni ścieków z przelewu burzowego po zmianie ilości ścieków odpływających w kierunku oczyszczalni ścieków, $h_{d}{ }^{\prime}=0,48 \mathrm{~m}$,

- wymagane napełnienie w kanale odpływowym w kierunku oczyszczalni ścieków z przelewu burzowego, zapewniające poprawny rozdział strugi ścieków po zmianie ilości ścieków odpływających kanałem odpływowym, $h_{d}{ }^{\prime}=0,44 \mathrm{~m}$,

- wykonanie wkładki piętrzącej nie zmienia wartości średniej prędkości przepływu ścieków na końcu kanału dopływowego do przelewu.

Kąt środkowy wyznaczony przez zwierciadło ścieków na końcu kanału dopływowego do przelewu burzowego przed wykonaniem wkładki piętrzącej wyznaczono ze wzoru (3):

$$
\gamma=360^{\circ}-2 \arccos \frac{h_{g}-r}{r}=360^{\circ}-2 \arccos \frac{0,65-0,4}{0,4}=257,36^{\circ}
$$

Pole powierzchni przekroju poprzecznego zajmowane przez przepływ obliczeniowy na końcu kanału dopływowego do przelewu burzowego bocznego przed wykonaniem wkładki piętrzącej ustalono na podstawie równania (1):

$$
\begin{aligned}
& f_{k c z}=\frac{\Pi \cdot d^{2}}{4} \cdot \frac{\gamma}{360^{\circ}}-\frac{d^{2}}{8} \cdot \sin \gamma=\frac{\Pi \cdot 0,8^{2}}{4} \cdot \frac{257,36^{\circ}}{360^{\circ}}-\frac{0,8^{2}}{8} \cdot \sin 257,36^{\circ}= \\
& =0,4374 m^{2}
\end{aligned}
$$

Przyjęto, że po zainstalowaniu wkładki piętrzącej średnia prędkość przepływu ścieków na końcu kanału dopływowego do przelewu nie uległa zmianie, 
a pole powierzchni czynnej zajmowane przez przepływ obliczeniowy po wykonaniu wkładki piętrzącej również pozostaje na stałym poziomie, zatem uzyskano powierzchnie $f_{k c z}=f_{k c z}$ '.

Zakładając wartość kąta środkowego równą $\beta=116^{\circ}$, obliczono wymaganą wysokość spiętrzenia ścieków na wylocie z kanału dopływowego do przelewu burzowego z zależności (4):

$$
\begin{aligned}
& h_{g}{ }^{\prime \prime}=\frac{f_{k c z}{ }^{\prime}-\frac{\Pi \cdot d^{2}}{4} \cdot \frac{\beta}{360^{\circ}}+\frac{d^{2}}{8} \cdot \sin \beta}{d \cdot \sin \frac{\beta}{2}}+\frac{d}{2} \cdot\left(1-\cos \frac{\beta}{2}\right)= \\
& =\frac{0,4374-\frac{\Pi \cdot 0,8^{2}}{4} \cdot \frac{116^{\circ}}{360^{\circ}}+\frac{0,8^{2}}{8} \cdot \sin 116^{\circ}}{0,8 \cdot \sin \frac{116^{\circ}}{2}}+\frac{0,8}{2} \cdot\left(1-\cos \frac{116^{\circ}}{2}\right)=0,71 \mathrm{~m}
\end{aligned}
$$

Dla dobranej wkładki piętrzącej sprawdzono czy zwierciadło ścieków nie znajduje się powyżej jej górnej krawędzi korzystając ze wzoru (5):

$$
\begin{aligned}
& h_{g}^{\prime} \leq \frac{d}{2} \cdot\left(1-\cos \frac{\beta}{2}\right)+d \cdot \sin \left(90^{\circ}-\frac{\beta}{2}\right) \\
& 0,71 \leq \frac{0,8}{2} \cdot\left(1-\cos \frac{113^{\circ}}{2}\right)+0,8 \cdot \sin \left(90^{\circ}-\frac{113^{\circ}}{2}\right) \\
& 0,71 \mathrm{~m} \leq 0,61 \mathrm{~m}
\end{aligned}
$$

Ponieważ warunek nie został spełniony, zastosowano drugi tok obliczeniowy. Pole powierzchni czynnej przekroju poprzecznego zajmowane przez przepływ do poziomu górnej krawędzi wkładki obliczono ze wzoru (6):

$$
\begin{aligned}
& f_{k c z}{ }^{\prime}=\frac{\Pi \cdot d^{2}}{4} \cdot \frac{\beta}{360^{\circ}}-\frac{d^{2}}{8} \cdot \sin \beta+d \cdot \sin \frac{\beta}{2} \cdot d \cdot \sin \left(90^{\circ}-\frac{\beta}{2}\right)= \\
& =\frac{\Pi \cdot 0,8^{2}}{4} \cdot \frac{116^{\circ}}{360^{\circ}}-\frac{0,8^{2}}{8} \cdot \sin 116^{\circ}+0,8 \cdot \sin \frac{116^{\circ}}{2} \cdot 0,8 \cdot \sin \left(90^{\circ}-\frac{116^{\circ}}{2}\right)= \\
& =0,3777 \mathrm{~m}^{2}
\end{aligned}
$$

Pozostałe pole powierzchni czynnej przekroju poprzecznego w kanale dopływowym zajmowane przez przepływ obliczeniowy wyznaczono z zależności (7): 


$$
f_{\text {kczp }}=f_{k c z}-f_{k c z}{ }^{\prime \prime}=0,4374-0,3777=0,0597 \mathrm{~m}^{2}
$$

Kąt środkowy wyznaczony przez zwierciadło ścieków w kanale po wykonaniu wkładki piętrzącej obliczono ze wzoru (8):

$$
\delta=2 \arccos \left(\frac{h_{g}^{\prime}-\frac{d}{2}}{\frac{d}{2}}\right)=2 \arccos \left(\frac{0,71-\frac{0,8}{2}}{\frac{0,8}{2}}\right)=78,4^{\circ}
$$

Pole powierzchni czynnej przekroju poprzecznego powyżej górnej krawędzi wkładki piętrzącej wyznaczono z zależności (9):

$$
\begin{aligned}
& f_{k c z}{ }^{\prime}=\frac{\Pi \cdot d^{2}}{4} \cdot \frac{\beta}{360^{\circ}}-\frac{d^{2}}{8} \cdot \sin \beta-\frac{\Pi \cdot d^{2}}{4} \cdot \frac{\delta}{360^{\circ}}+\frac{d^{2}}{8} \cdot \sin \delta= \\
& =\frac{\Pi \cdot 0,8^{2}}{4} \cdot \frac{116^{\circ}}{360^{\circ}}-\frac{0,8^{2}}{8} \cdot \sin 116^{\circ}-\frac{\Pi \cdot 0,8^{2}}{4} \cdot \frac{78,4^{\circ}}{360^{\circ}}+\frac{0,8^{2}}{8} \cdot \sin = \\
& =0,0597 \mathrm{~m}^{2}
\end{aligned}
$$

Zatem ustalone pola powierzchni czynnej obliczone dwoma metodami są sobie równe i spełniają wyżej założony warunek.

W celu uzyskania spiętrzenia ścieków na poziomie $h_{g} "=0,71 \mathrm{~m}$ na końcu kanału dopływowego do przelewu burzowego należy wykonać wkładkę piętrzącą o wymiarach przedstawionych na rysunku 7.

\section{Podsumowanie}

Sieci kanalizacyjne i obiekty z nią współdziałające są projektowane na długi okres użytkowania, nawet stu lat i więcej. W czasie eksploatacji systemów kanalizacyjnych następuje zmiana bilansu przepływających ścieków, co w wielu przypadkach wymusza konieczność modernizacji ich elementów.

Konieczność modernizacji konwencjonalnego przelewu burzowego wystąpi wówczas, gdy istniejąca długość krawędzi przelewowej przy uzyskanej wysokości strugi nad krawędzią przelewową okaże się zbyt krótka do efektywnego odprowadzenia nadmiaru ścieków ogólnospławnych do kanału burzowego. Zwiększenie długości krawędzi przelewowej zawsze wiąże się ze znaczną ingerencją w konstrukcję przelewu burzowego, co pociąga za sobą, oprócz znacznych nakładów finansowych, duże problemy realizacyjne. 


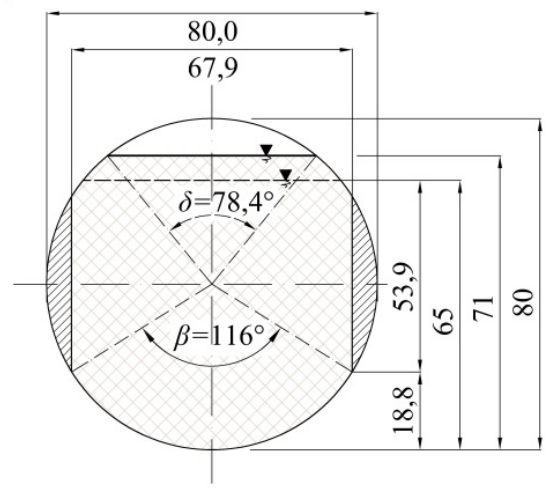

Rys. 7. Schemat usytuowania i geometrii wkładki piętrzącej wykonanej na końcu kanału dopływowego do przelewu burzowego

Fig. 7. Diagram of the location and geometry of uplifting insert performed at the end of the inlet canal to the storm overflow

Skutecznym, a zarazem tanim sposobem, jest wykonanie innowacyjnej wkładki piętrzącej na końcu (wylocie) kanału dopływowego do przelewu burzowego. Wkładka piętrząca o geometrii ustalonej na podstawie opracowanej metodologii zapewnia wymagane spiętrzenie ścieków na końcu tego kanału, co skutkuje zwiększeniem wysokości strugi nad krawędzią przelewową.

Wymiary wkładki powinny być tak dobrane, aby przy przepływie obliczeniowym wysokość zwierciadła ścieków na końcu kanału dopływowego pozwalała na uzyskanie wymaganej efektywności działania konwencjonalnego przelewu burzowego przy istniejącej długości krawędzi przelewowej. Warto podkreślić, że zamontowanie $\mathrm{w}$ kanale wkładki piętrzącej nie wiąże się $\mathrm{z}$ ingerencją w konstrukcję przelewu burzowego, a jej zastosowanie w sieciach kanalizacyjnych zapewnia ciągłą ich eksploatację.

Jedyną wadą wkładki piętrzącej zwiększającej efektywność działania przelewu burzowego jest zmniejszenie rzeczywistej powierzchni czynnej kanału dopływowego. Jednak zmniejszenie przepustowości hydraulicznej kanału po wykonaniu wkładki piętrzącej mieści się w zakresie kilku procent, co w praktyce nie ma istotnego wpływu na funkcjonowanie sieci zlokalizowanej powyżej przelewu burzowego.

\section{Literatura}

[1] Błaszczyk W., Stamatello P., Roman M.: Kanalizacja T1, Wydawnictwo Arkady, Warszawa 1974.

[2] Bolt A., Burszta-Adamiak E., i inni.: Kanalizacja. Projektowanie, wykonanie, eksploatacja, Wydawnictwo Seidel - Przywecki, 2012. 
[3] Brzezińska A., Zawilski M., Bandzierz D., Sakson G.: Wielkość emisji zanieczyszczeń z przelewów burzowych kanalizacji ogólnospławnej na przykładzie Łodzi, Czasopismo Inżynierii Lądowej, Środowiska i Architektury JCEEA, Oficyna Wydawnicza Politechniki Rzeszowskiej, nr 60, (1/13), s. 7-21.

[4] Dziopak J.: Analiza teoretyczna i modelowanie wielokomorowych zbiorników kanalizacyjnych, Monografia 125, Wydawnictwa Politechniki Krakowskiej, Kraków 1992.

[5] Dziopak J., Słyś D.: Modelowanie zbiorników klasycznych i grawitacyjno-pompowych w kanalizacji, Oficyna Wydawnicza Politechniki Rzeszowskiej, Rzeszów 2007.

[6] Dziopak J., Starzec M.: Wkładka piętrząca. Patent P.417492.

[7] Kordana S., Słyś D.: Analiza kosztów cyklu życia skrzynek rozsączających, Czasopismo Inżynierii Lądowej, Środowiska i Architektury JCEEA, Oficyna Wydawnicza Politechniki Rzeszowskiej, nr 61 (3/I/14), 2014, s. 127-139.

[8] Pochwat K.: Retencja wód opadowych w małych zlewniach miejskich, Politechnika Rzeszowska im. Ignacego Łukasiewicza, Wydział Budownictwa, Inżynierii Środowiska i Architektury, rozprawa doktorska, promotor: dr hab. inż. Słyś D. prof. PRz, Rzeszów 2015.

[9] Słyś D., Stec A.: Effect of development of the town of Przemyśl on the operation of its sewerage system, Ecological Chemistry and Engineering S, no. 20(2), 2013, s. 381-396.

[10] Suligowski Z.: Kanalizacja, Wydawnictwo Uniwersytetu Warmińsko-Mazurskiego, 2000.

\section{UPLIFTING INSERT INCREASING HYDRAULIC EFFICIENCY OF CONVENTIONAL STORM OVERFLOW IN SEWAGE SYSTEM}

\section{S u m m a r y}

The paper presents a solution of uplifting insert performed at the end of the inlet canal to the conventional storm overflow. Introducing of uplifting insert allows to improve the efficiency of storm overflow functioning by the increasing of the difference between wastewater levels at the end of the inlet canal and at the beginning of the outlet canal from storm overflow discharging wastewater to sewage treatment plant. The presented uplifting insertis an effective alternative in relation to the methods currently used to improve the efficiency of this type of storm overflows. In the article, together with the dimensioning methodology the course of calculation for determining of uplifting insert's geometry is also presented by posting two examples of its dimensioning.

Keywords: combined sewage system; dimensioning; storm overflows; calculative flow

DOI: $10.7862 / \mathrm{rb} .2016 .152$

Przestano do redakcji: 01.05.2016 r.

Przyjęto do druku: 28.06.2016 r. 